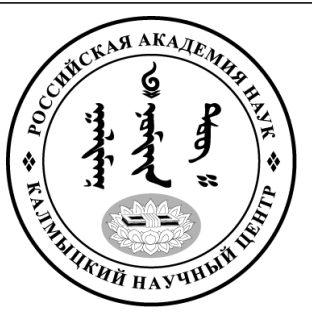

Published in the Russian Federation

Oriental Studies (Previous Name: Bulletin of the Kalmyk Institute

for Humanities of the Russian Academy of Sciences)

Has been issued as a journal since 2008

ISSN: 2619-0990; E-ISSN: 2619-1008

Is. 5, pp. 926-937, 2019

DOI: $10.22162 / 2619-0990-2019-45-5-926-937$

Journal homepage: https://kigiran.elpub.ru

УДК 394.2+394.4

\title{
Коллекция В. П. Ермолаева как этнографический источник изучения материальной и духовной культуры тувинского этноса (часть 2)*
}

Елена Валерьевна Айыжы ${ }^{1}$, Марианна Маадыр-ооловна Мандан-Хорлу ${ }^{2}$ Алдармаа Чулдумовна Монгуші

${ }^{1}$ Тувинский государственный университет (д. 36, ул. Ленина, 667000 Кызыл, Российская Федерация)

кандидат исторических наук, доцент

ORCID: 0000-0002-4289-3543. E-mail: aiygy@mail.ru

${ }^{2}$ Национальный музей имени Алдан-Маадыр Республики Тыва (д. 30, ул. Титова, 667000 Кызыл, Российская Федерация)

заведующий отделом учета и хранения фондов

ORCID: 0000-0002-8105-2093. E-mail: mandan-horlu@yandex.ru

${ }^{3}$ Национальный музей имени Алдан-Маадыр Республики Тыва (д. 30, ул. Титова, 667000 Кызыл, Российская Федерация)

хранитель I категории, отдел учета и хранения фондов

ORCID: 0000-0002-9912-0701. E-mail: maldarmaa@mail.ru

Аннотация. Данная статья посвящена составу коллекции В. П. Ермолаева (1892-1982), первого директора Национального музея Республики Тыва, краеведа, фотографа. Цель работы — исследование состава коллекции В. П. Ермолаева, ее систематизация с учетом тематики экспонатов, а также анализ проблем ее атрибуции (определения хронологических рамок) и сохранения коллекции. Материальl. В статье описываются состав коллекции В. П. Ермолаева, ее тематика, структура и хронологические рамки. Фототека В. П. Ермолаева насчитывает более 4000 единиц хранения. Результаты. Авторами статьи представлены итоги систематизации коллекции по тематическому принципу. Большое внимание уделено изучению истории поступления и формирования коллекции. Выводы. В результате исследования выявлено, что формирование огромного труда работ В. П. Ермолаева шло постепенно, в течение нескольких десятилетий. По результатам изучения музейной учетной документации и самих фотодокументов авторы пришли к выводу, что в фотодокументы В. П. Ермолаева входят не только негативы, но и альбомы с контрольными отпечатками и фотографиями, к большинству снимков автор дал собственные комментарии. Анализ проделанной работы позволяет сделать вывод, что В. П. Ермолаев был одним из первых исследователей, использовавших фотографию в качестве основного метода сбора информации и научного исследования социокультурного развития Тувы.

* Статья является продолжением опубликованной в предыдущем номере журнала первой части. См.: [Айыжы, Мандан-Хорлу, Монгуш 2019]. 
Ключевые слова: Владимир Петрович Ермолаев, Национальный музей им. Алдан-Маадыр Республики Тыва, музейная коллекция, фотография, стеклянные и пленочные негативы

Благодарность. Исследование выполнено при финансовой поддержке РФФИ в рамках научного проекта № 19-012-00073.

Для цитирования: Айыжы Е. В., Мандан-Хорлу М. М., Монгуш А. Ч. Коллекция В. П. Ермолаева как этнографический источник изучения материальной и духовной культуры-тувинского этноса (часть 2). Oriental Studies. 2019; (5): 926-937. DOI: 10.22162/2619-0990-2019-45-5-926-937.

UDC $394.2+394.4$

\title{
V. P. Yermolaev's Collection as an Ethnographic Source for Studies of Tuvan Material and Spiritual Culture. Part 2
}

\author{
Elena V. Ayizhy ${ }^{1}$, Marianna M. Mandan-Khorlu' ${ }^{2}$ Aldarmaa Ch. Mongush ${ }^{3}$ \\ ${ }^{1}$ Tuvan State University (36, Lenin St., 667000 Kyzyl, Russian Federation) \\ Cand. Sc. (History), Associate Professor \\ ORCID: 0000-0002-4289-3543. E-mail: aiygy@mail.ru \\ ${ }^{2}$ Aldan Maadyr National Museum of the Republic of Tuva (30, Titov St., 667000 Kyzyl, Russian \\ Federation) \\ Head of Museum Collection Records Department \\ ORCID: 0000-0002-8105-2093.E-mail: mandan-horlu@yandex.ru \\ ${ }^{3}$ Aldan Maadyr National Museum of the Republic of Tuva (30, Titov St., 667000 Kyzyl, Russian \\ Federation) \\ First-Class Custodian, Museum Collection Records Department \\ ORCID: 0000-0002-9912-0701.E-mail: maldarmaa@mail.ru
}

\begin{abstract}
The article examines the structure of the collection compiled by V. P. Yermolaev (18921982), the first director of Tuva's National Museum, expert in local history, photographer. Goals. The work seeks to investigate the structure of V. P. Yermolaev's collection, systematize it thematically and analyze problems of its attribution (define the chronological framework). Materials. The paper describes the development of V. P. Yermolaev's collection, its subject, structure and chronological framework. The collection of photo documents by V. P. Yermolaev comprises photographs and negatives (glass and film ones) numbering over 4,000 storage items. Results. The article systematizes the collection thematically. The history of receipt and formation of the collection is paid special attention to. Conclusions. The study reveals that the formation of the collection was gradual and lasted over several decades. The insight into museum records and photo documents as such concludes that V. P. Yermolaev's collection of photo documents comprises not only negatives but also albums with control prints and photographs largely supplemented with the author's own comments. The analysis allows concluding that V. P. Yermolaev was one of the first researchers to have used photography as a key method of data collection and research of Tuva's sociocultural development.

Keywords: Vladimir P. Yermolaev, Aldan Maadyr National Museum of the Republic of Tuva, museum collection, photograph, glass and film negatives

Acknowledgements: The reported study was funded by RFBR, project number 19-012-00073.

For citation: Ayizhy E. V., Mandan-Khorlu M. M, Mongush A. Ch. V. P. Yermolaev's Collection as an Ethnographic Source for Studies of Tuvan Material and Spiritual Culture. Part 2. Oriental Studies. 2019; (5): 926-937. DOI: 10.22162/2619-0990-2019-45-5-926-937.
\end{abstract}




\section{Введение}

Фотография как музейный предмет, прежде всего, является историческим источником. Это одновременно изображение и документ, фиксирующий факты реальной действительности и регистрирующий мельчайшие детали происходящего процесса, - визуальный документ. Информативность фотографии актуализирует вопросы её изучения, сохранения и экспонирования как культурного наследия. Этим объясняется непреходящий интерес к фотографии. Фотоснимок зачастую является главным и единственным объективным свидетелем прошедшего времени [Фотография 1992: 6].

Актуальность темы. В первой части статьи [Айыжы, Мандан-Хорлу, Монгуш 2019] освещалась история создания коллекции Владимира Петровича Ермолаева, которая включает фотографии и негативы (стеклянные и пленочные), всего более 4000 единиц хранения. Остается проблемным определение состава фотоматериалов: считать ли альбомы сопроводительным справочным аппаратом или полноценной частью коллекции? Кроме того, до настоящего времени не уточнено, какие территории Тувы были запечатлены В. П. Ермолаевым за сорокапятилетний период, за который он «по особой программе вел систематические фотосъемки природы Тувы, быта населения, занятий, промыслов, различных моментов общественной и государственной жизни» [НМ РТ. Ф. 1. Д. 410. Л. 27]. Назрела необходимость расширения исследований, дальнейшего комплексного изучения работ В. П. Ермолаева, на что обращает внимание и О. О. Монгуш: многие негативы не аннотированы, не имеют описаний, кто, где и когда запечатлен на снимке [Монгуш 2013: 43]. Таким образом, коллекция В. П. Ермолаева в целом комплексно не описана. Авторами делается попытка распределить фототеку по темам и провести ее систематизацию.

Целью данного исследования (второй части статьи) является описание состава и основной тематики коллекции, хронологических и территориальных рамок фотодокументов В. П. Ермолаева как части этнографических материалов по изучению истории, политики и культуры Тувы, а также анализ проблем атрибуции и сохранения собрания.

\section{Основная часть}

Анализ имеющихся источников позволяет сделать вывод, что коллекция формировалась исторически и состоит из разных компонентов.

В первую очередь, конечно, это коллекция фотонегативов. По учетной документации музея в целом от В. П. Ермолаева поступило 4758 негативов. Они подразделяются по материалу на стеклянные и пленочные негативы. В свою очередь, пленочные - на зафиксированные на широкоформатной и на перфорированной узкой пленке. Исторически так сложилось, что фотонегативы делятся на две части, или две подколлекции. Первая - «Фотонегативы В. П. Ермолаева» - под номером 1фо/1-4356; позже, с 2009 г., она идет под номером КП 11286/1-4356. Другая — «Город Кызыл 1914-1960 гг.» - под номерами 2855фо-2873фо; с 2009 г. она идет под номером КП 11286/12739-13399.

Как уже писала А. М. Ооржак, «коллекция в силу своего „возраста“, хрупкости ее носителей (стеклянных фотонегативов), уникальности информации, содержащейся в ней, до недавнего времени являлась закрытым фондом, доступность которого была строго ограничена» [Ооржак 2009: 160]. Наиболее приемлемым способом сохранения подобных коллекций музейное сообщество видело в их оцифровке, т. е. в переводе в цифровой или электронный вид. Надо сказать, что в мировой практике оцифровка действительно оказалась самым доступным способом сохранения фотодокументов, благодаря которому коллекции также стали активно публиковаться. Национальный музей РТ впервые к оцифровке приступил в 2003-2004 гг. с коллекции В. П. Ермолаева. К работе был привлечен В. М. Балчый-оол, фотокорреспондент газеты «Шын», который оцифровал 1035 стеклянных негативов. Со слов исполнителя, была оцифрована вся коллекция стеклянных негативов. На тот момент это было важным достижением 
в деле сохранения коллекции. Оцифровку негативов В.П. Ермолаева продолжил художник В. Н. Елизаров. В основном он редактировал оцифрованные работы В. М. Балчый-оола, значительно увеличил расширение. Им оцифровано в 2007-2008 гг. 858 негативов. Подготовленная В. Н. Елизаровым часть фотографий была опубликована в альбоме С. К. Шойгу «Черно-белая Тува: незаконченная история...» [Черно-белая Тува 2011]. Оставшаяся часть коллекции «Фотонегативы В. П. Ермолаева» была оцифрована одним из авторов данной статьи - А. Ч. Монгуш.

По результатам проведенной в 2017 2018 гг. ответственным хранителем «Фотофонда» А. Ч. Монгуш сверки наличия музейных предметов фондовой коллекции «Фотонегативы В. П. Ермолаева», т. е. первой части или подколлекции, с учетной документацией и результатом государственной сверки данной коллекции 2002 г. [НМ РТ. Акт сверки № 8 от 28.10.2002] выявлено, что на сегодняшний день в первой части коллекции фактически насчитывается 3913 фотонегативов. В коллекционной описи обнаружена техническая ошибка, заключающаяся в том, что после № 3156 сразу следует запись под № 3557, следовательно, пропущены 400 (четыреста) номеров, поэтому число предметов в списке оказалось 3956 вместо 4356 единиц. При сравнении полученных данных с результатами сверки 2002 г. подтвердилось отсутствие 43 негативов, выявленное еще в 2002 г. [НМ РТ. Акт сверки от 19.11.2018 г.]

Сверка наличия музейных предметов и автоматизированный учет позволили определить точное количество негативов в первой части коллекции по материалу: стеклянных негативов всего 1199 экземпляров, широкоформатных пленочных - 1066 единиц хранения и перфорированных пленочных - 1648.

Самые ранние снимки относятся к 1913 г., их всего двадцать один: стеклянных подлинных негативов - тринадцать, на обоих видах пленки - восемь. Последний снимок в коллекции датируется 1959 г. Не имеют датировку 424 снимка. Распределение по видам и датировке можно увидеть по диаграмме 1.

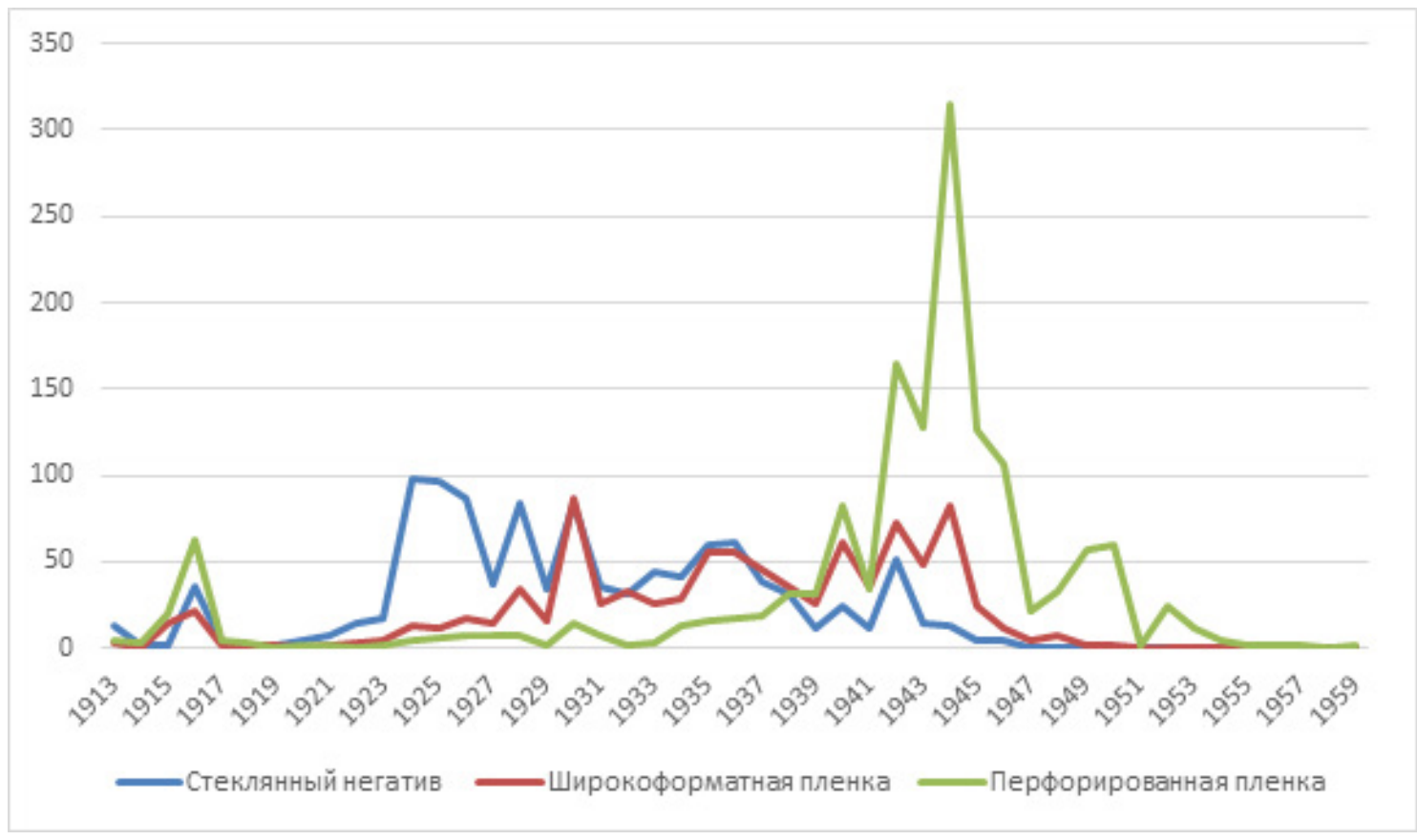

Диаграмма 1. Распределение коллекции по видам негативов и датировке

[Diagram 1. Collection segments by types and dates of negatives] 
Из диаграммы видно, что самое большое количество стеклянных негативов датированы 1924-1926, 1928 гг., широкоформатной пленки — 1930, 1942, 1944 гг., а перфорированной пленки - 1944 г. Это объясняется тем, что в указанные годы В. П. Ермолаев работал сначала фотографом в музее, а затем фотокорреспондентом и литературным работником - в газете «Тувинская правда» (диаграмма № 2) с 1944 по 1949 гг. [НМ РТ. Автобиография В. П. Ермолаева. Ф. 1. Д. 195. Л. 40].

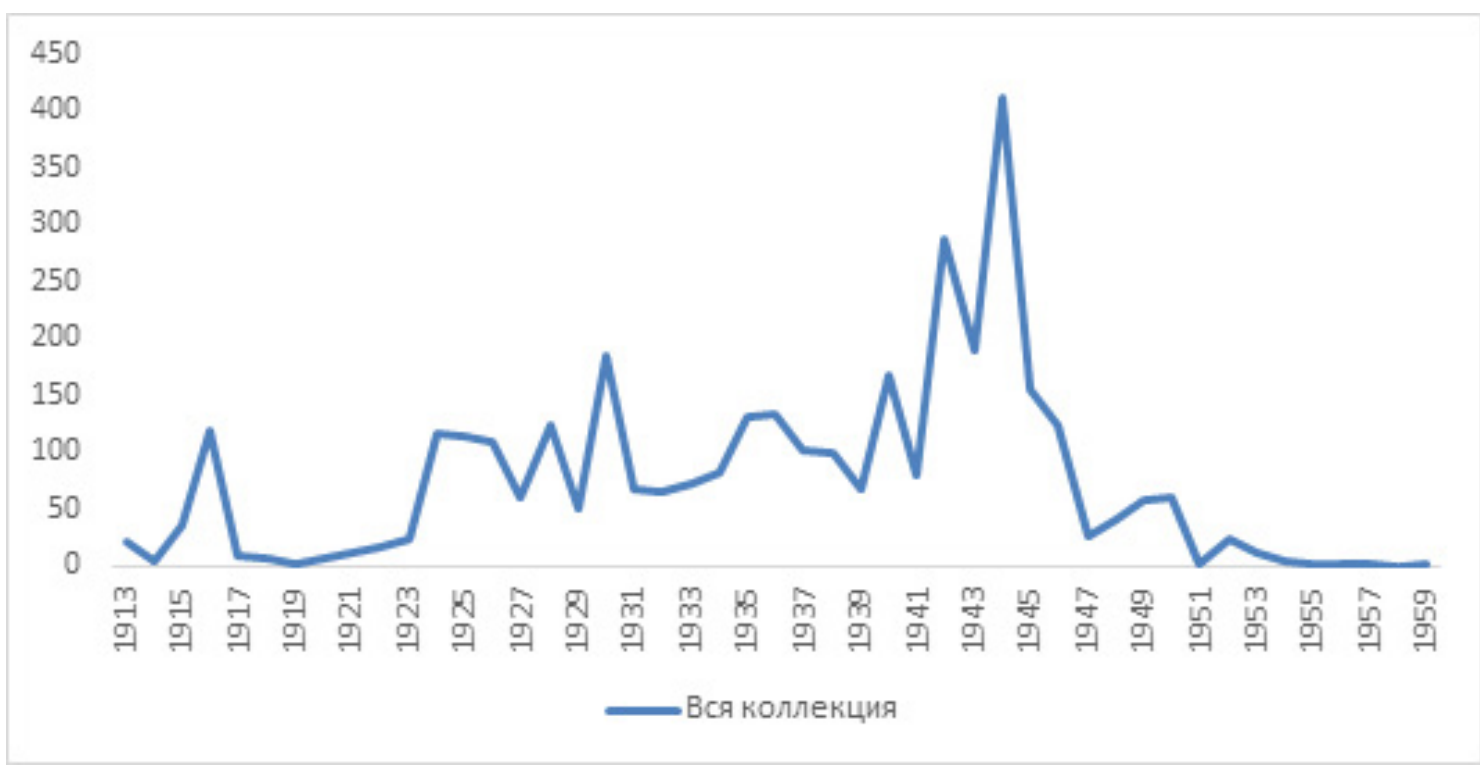

Диаграмма 2. Распределение негативов

с датировкой коллекции «Фотонегативы В. П. Ермолаева» по годам

[Diagram 2. Distribution of negatives identified

as 'V. P. Yermolaev's Photographic Negatives' by years]

Ко второй коллекции или подколлекции, зарегистрированной под номерами с 2855 фо по 2873фо 28 августа 1979 г. [НМ РТ. Инвентарная книга № XI-3, 140-144], следует отнести поступление фотонегативов с контрольными отпечатками по теме «Кызыл. 1914-1960 годы» 1979 г. [НМ РТ. Акт приемки-сдачи от 18.06.1979 г.]. Данная коллекция состоит из 19 пленок, содержащих 661 кадр. Тематика и хронологические рамки коллекции уже даны в ее названии. Наличие коллекции в полном объеме сверено в июне 2019 г. [НМ РТ. Акт сверки № 8 от 13.06 .2019 г.].

Итого, стеклянные негативы - наиболее ранняя часть коллекции - составляют 1199 единиц хранения. Остальные 2714 и плюс 661 кадр второй коллекции, всего 3375 единиц - пленочные негативы разного формата. Есть еще некоторое количество стеклянных негативов в фондах Национального музея, зарегистрированных в 1960 г. в Инвентарной книге № 2 как негативы музея, авторство которых предстоит установить.
В собрании Красноярского краевого краеведческого музея, по данным М. С. Баташева и Н. В. Мартынович, хранится около 20000 единиц стеклянных негативов, из них этнографической тематики - не менее 2000 экземпляров ${ }^{1}$.

М. С. Баташев и Н. В. Мартынович отмечают: «Негативы, переданные в музей братьями Ермолаевыми, не всегда можно четко разделить по авторству. Общее количество фотографических снимков на стекле,

${ }^{1}$ Обращение к собранию Красноярского музея связано с тем, что В. П. Ермолаев свою музейную трудовую деятельность начал именно с этого музея. И если в Красноярском музее даже по этнографической тематике представлены стеклянные негативы 15 авторов - П. Е. Островских, Н. А. Шепетковского, А. Г. Куркутова, Попова, Л. Ю. Вонаго, А. Я. Тугаринова, П. В. Тюрина, А. В. Кудрявцева, Н. А. Остроумова, М. К. Калашникова, Е. О. Яковлева, Копылова, И. И. Балуева и братьев А. П. и В. П. Ермолаевых, то стеклянные негативы тувинского музея не отличаются разнообразием авторства. В большинстве своем они принадлежат В. П. Ермолаеву. 
поступивших от братьев в музей за период с 1911 по 1921 гг., также приближается к тысяче, в том числе около двухсот по этнографии. Подавляющее большинство касается коренного населения Урянхайского края, Тоджи и Минусинского округа» [Баташев, Мартынович 2007: 98].

Суммируя количество поступивших негативов по первым 5 актам, мы получили число 4095 (без учета последних 19 пленочных негативов из 661 кадра и 2 единичных поступления). Сопоставив данные актов и описей, получили разницу в 139 ед. Возникает вопрос, который остается открытым: почему возникла такая разница?

Поступление негативов В. П. Ермолаева сопровождали альбомы с контрольными отпечатками с негативов. Всего в фотофонде музея хранится тридцать один альбом В. П. Ермолаева, из них двенадцать фотоальбомов имеют основные номера, т. е. являются музейными предметами основного фонда.

При сверке отсутствующих негативов с контрольными отпечатками оказалось, что из 43 негативов 38 имеют контрольные отпечатки, т. е. можно по ним восстановить их изображения. Остальные 5 негативов под №№ 130, 258, 2335, 3787, 4279 можно считать утраченными, так как отсутствуют и негативы, и контрольные отпечатки. Несмотря на то, что первоначально альбомы носили рабочий характер, со временем они стали приобретать большое значение, так как по ним стало возможным восстановление снимков утраченных негативов. Кроме этого, контрольные отпечатки в части альбомов сопровождаются комментариями самого автора, благодаря чему они обретают еще большую значимость. Авторы статьи считают, что фотоальбомы нужно признать полноценной частью коллекции фотодокументов В. П. Ермолаева, несмотря на то, что они дублируют изображения негативов, в том числе и потому, что они являются авторскими фотоотпечатками.

Тематика коллекции В. П. Ермолаева и проблемы атрибуичи

Названия фотоальбомов отражают направления исследований, самостоятельно проведенных В. П. Ермолаевым, и хранятся под этими наименованиями:

- «Здравоохранение», №oo 97-129 (фактически в наличии 38 фотографий ${ }^{2}$ );

2 Далее в списке также дается количество фотографий в наличии на сегодняшний день.
- «История г. Кызыла», №№ 130-256 (128 фотографий);

- «Физкультура, спорт, национальная борьба, армия ТНР, Тува в дни Отечественной войны 1941-1945 гг.», №№ 285-401 (113 фотографий);

- «Народное образование Тувы», №№ 402525 (113 фотографий);

- «Искусство Тувы 1913-1945 гг.», №№ 526-598 (74 фотографии);

- «Люди новой Тувы 1913-1945 гг.», №o 600-662 (60 фотографий);

- «Торговля и промыслы Тувы 19131945 гг.», №№ 663-766 (112 фотографий);

- «Старая Тува. 1913-1945 гг.», №№ 767854 (79 фотографий о быте);

- «Старая Тува. Религия. Изменение одежды», №№ 855-942 (69 фотографий);

- «Пути и средства сообщения Тувы 19131945 гг.», №№ 944-1039 (102 фотографии);

• «Земледелие 1913-1945 гг.», №№ 10401112 (70 фотографий);

- «Животноводство в дореволюционной Туве и в ТНР», №№ 1113-1215 (120 фотографий).

В следующих двух альбомах нумерация снимков собственная, не соответствующая коллекционной описи:

- «Наводнение 1937 г.» (58 фотографий);

- «Наводнение 1945 г.» (61 фотография).

Вполне возможно, что эти два альбома не относятся к альбомам с контрольными отпечатками, так как в коллекционной описи тоже нет разделов по наводнениям. Тогда из негативов, сопровождаемых контрольными отпечатками, выпадают номера с № 1216 по 2783, т. е. 1567 единиц. Так как в следующих двух небольших фотоальбомах наклеены так называемые «контрольные отпечатки» (фотоотпечатки размером 2х2 см) с номерами по описи, условно 15-й альбом - с 2784 по 3876 (фактически в наличии 706 фотографий); условно 16-й альбом - с 3877 по 4356 (468 фотографий).

- «ТНР в дни Великой Отечественной войны» - 557«а», позже перерегистрирован под номером КП 2435 (по инв. книге 56, фактически - 50 фотографий);

- «ТНР в дни Великой Отечественной войны» - 557«б», позже перерегистрирован под номером КП 2445 (по инв. книге 93, фактически - 82 фотографии); 


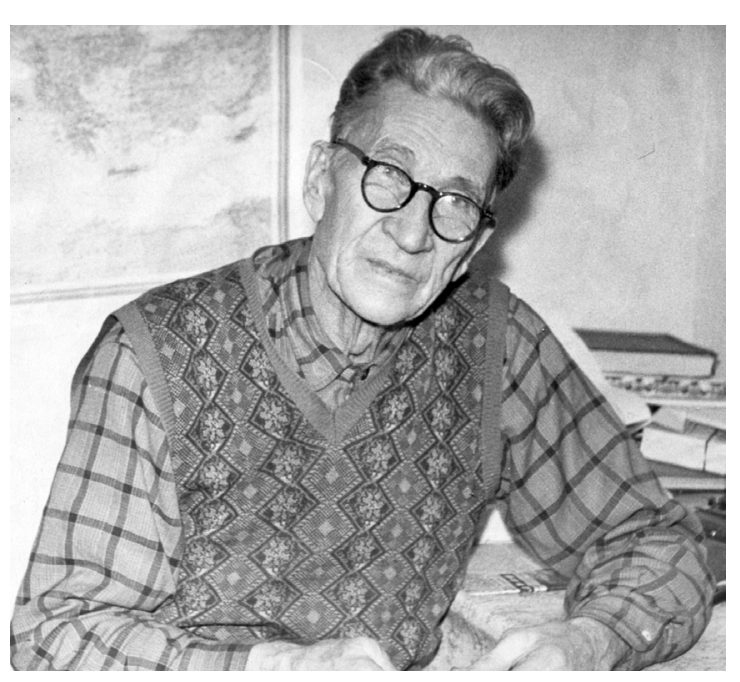

Фото 1. Владимир Петрович

Ермолаев. Абакан, 1965 г. (КП 11677/7)

[Photo 1. Vladimir P. Yermolaev. Abakan, 1965]

- «ТНР в дни Великой Отечественной войны» - 557《в», позже перерегистрирован под номером КП 2434 (по инв. книге 27, фактически - 41 фотография);

- «ТНР в дни Великой Отечественной войны» - 559, перерегистрирован под номером КП 2444 (по инв. книге 32, фактически - 28 фотографий);

- «Экспозиция музея ТНР в 1940-е годы»565 (по инв. книге 81, фактически - 70 фотографий);
- «Тувинская Автономная Область» - КП 2430 (360 фотографий);

- «25 годовщина тувинской национально-освободительной революции, 17 августа 1946 года» — КП 2437 (222 фотографий);

- «Природа. Улуг-Хемский и Хемчикский районы» - КП 2327 (175 фотографий на 14 листах);

- Фотографии на общую тему «Центральные районы» - КП 2328 (249 фотографий на 18 листах);

- «Центральные районы (II часть)» - КП 2329 (283 фотографий на 22 листах);

- «Природа. Тандинский, Эрзинский, Тес-Хемский, Каа-Хемский районы» - КП 2330 (254 фотографий на 23 листах);

- «Природа. Пий-Хемский и Тоджинский районы» - КП 2331 (209 фотографий на 16 листах); Альбомы под №№ 2327 по 2331 зарегистрированы 3 января 1977 г. [НМ РТ. Инвентарная книга № XI-3: 62];

- «Быт арата № 1» (454 фотографий);

- «Природа ТНР № 2» (293 фотографий);

- «Кызыл 1935-1940 гг.» (последнее поступление 2014 года под КП 11673/24) (64 фотографии).

Коллекционная опись, составленная при поступлении основной части коллекции, уже была сформирована тематически. Она начинается с раздела «Собрания, заседания,

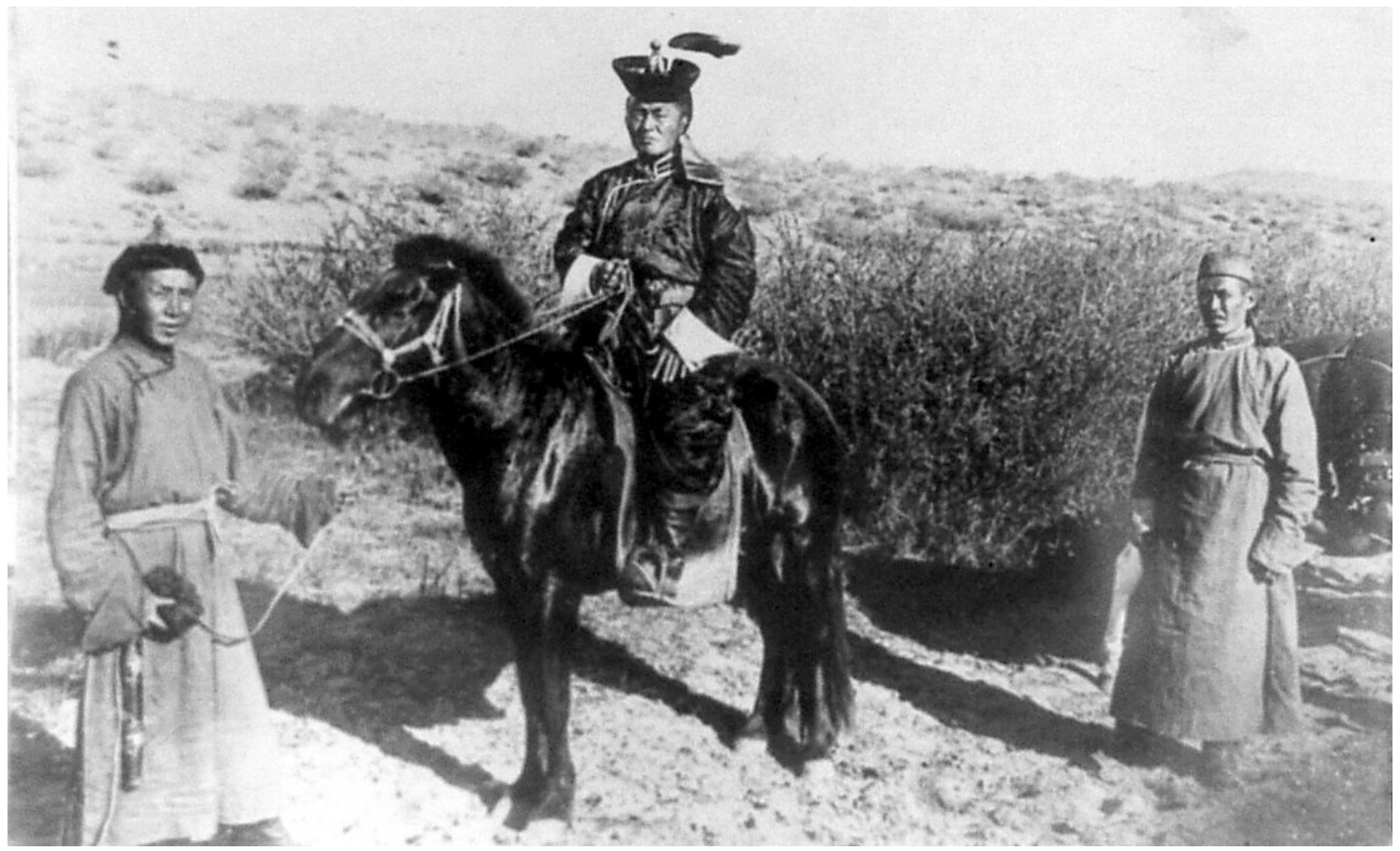

Фото 2. Салчакский нойон Идам-Сюрюн. 1915 г. (КП 11286/856)

[Photo 2. Salchak noyon Idam-Syuryun. 1915] 
съезды, группы», отражающего политическую жизнь ТНР, далее идут «Здравоохранение», «Кызыл», «Физкультура, спорт, национальная борьба, армия ТНР, Тува в дни Отечественной войны 1941-1945 гг.», «Народное образование», «Искусство», «Люди новой Тувы», «Торговля и промыслы», «Старая Тува», «Старая Тува. Религия. Изменение одежды», «Одежда» и т. д. Таким образом, основная тематика фотодокументов В. П. Ермолаева по коллекционной описи в основном соответствует тематике альбомов, сформированных по разделам описи. Последние шестнадцать, возможно даже восемнадцать (если включить два альбома по наводнениям) альбомов, не являются сопроводительным вспомогательным аппаратом, а были целенаправленно тематически сформированными фотоальбомами автора.

Атрибуциия. Сотрудником отдела фондов Т. М. Скаковой с участием партийного и государственного деятеля 1930-1944 гг. Х. К. Базыр-Сата была проведена частичная атрибуция коллекции: были определены имена политических деятелей на фотографиях и составлена 30 марта 1959 г. отдельная от коллекционной (при поступлении коллекции) опись.

В нескольких своих публицистических рассказах В. П. Ермолаев описывает истории, связанные с персонажами снимков. Так, во втором рассказе «Путешествие в экзотику» из пяти, объединённых общим названием «Давно это было», опубликованном в литературном альманахе «Улуг-Хем», Владимир Петрович пишет, что «Акцизный чиновник А. Е. Скороходов, побывавший за Саянами в 1910 году, принес в Красноярский музей стеклянные негативы, снятые в Урянхае (в Туве. - авт.)» [Ермолаев 1967: 133].

Далее он повествует, как ему посчастливилось побывать в Туве в 1913 г. в составе почвенно-ботанической экспедиции Академии наук [Ермолаев 1967: 133-138].

Встречи на пути экспедиции были зафиксированы В. П. Ермолаевым фотоаппаратом. Встречу с салчакским нойоном возле Турана он описывает так: «Среди дня наш караван развьючился у ворот поскотины. Только успели поставить палатки, смотрим, со стороны Уюка скачет несколько всадников. Впереди на сером иноходце летел человек в ярком коричневом халате и

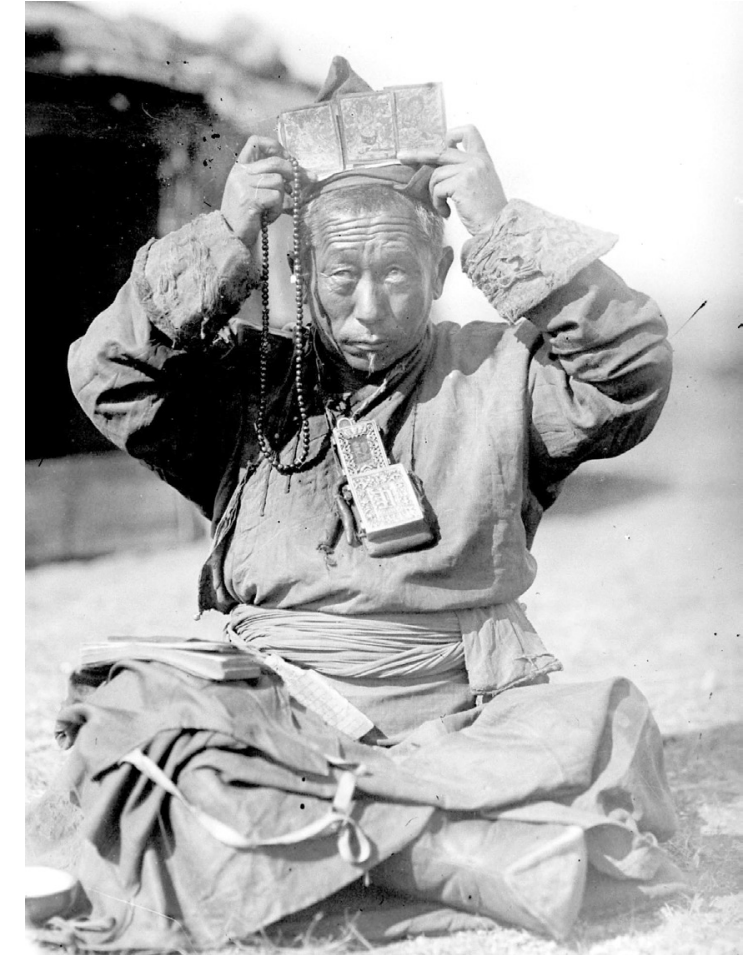

Фото 3. Лама-лекарь. 1916 г. (КП 11286/98) [Photo 3. Healer Lama. 1916]

в шапке, украшенной красным шариком и „метелкой“ из павлиньих перьев. Всадник остановился у ворот поскотины. Тотчас же двое из сопровождавших его людей соскочили с коней и бросились открывать ворота, при этом они так низко склоняли головы перед начальником, будто боялись ослепнуть от его блистательного величия. После нам рассказали, что это был салчакский нойон, ехавший в Туран с визитом к новому пограничному начальнику Габаеву» [Ермолаев 1967: 138].

На снимке «Салчакский нойон ИдамСюрюн» (КП 11286/856) запечатлены трое мужчин в степи. В центре всадник на низкорослом коне перед караганником. Одет в национальный шелковый тон темного цвета с длинными рукавами. На голове у мужчины чиновничий головной убор - чинзелиг бөрm с шариком из драгоценного камня чинзе, подставкой под шарик одага и павлиньим пером - алдын-доос. От головного убора спускается на плечи широкая лента мумак. С чиновничьей одеждой более подробно можно ознакомиться в монографии Р. Б. Ховалыг «Тувинская традиционная одежда. Тыва үндезин хеп» [Ховалыг 2018: 31-43], в частности, с описанием головного убора [Ховалыг 2018: 37-39]. Стоящий слева 


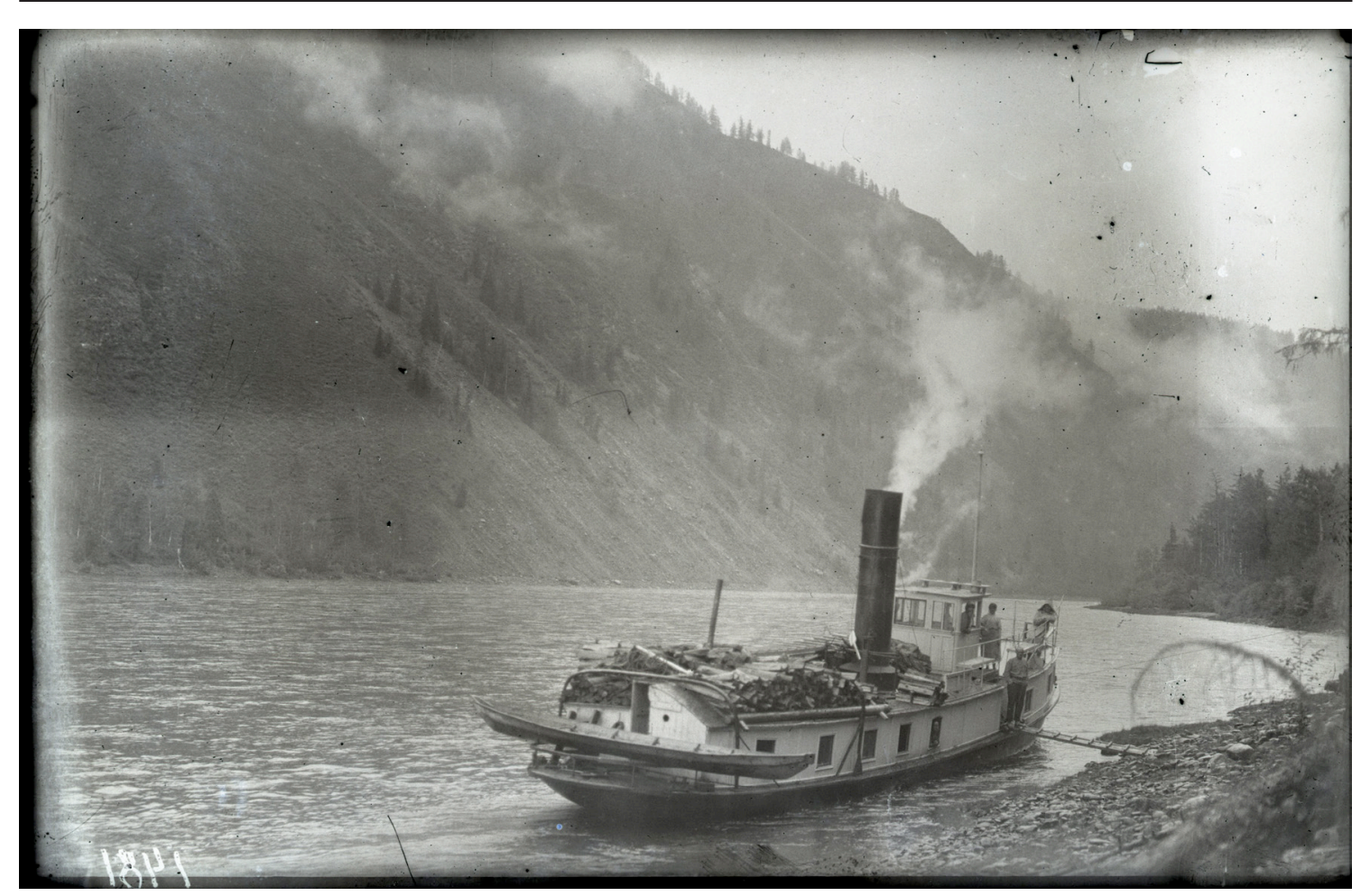

Фото 4. Первый пароход в Туве «Минусенок» на пути к Хутинскому порогу. 1925 г. (КП 11286/3914)

[Photo 4. Tuva's first steamer 'Minusenok' on its way to the Khutinsky Rapids. 1925]

Фото 5. Пароход «Минусинск», недалеко от Бегреды, Пий-Хем (КП 11286/1945)

[Photo 5. Steamer 'Minusenok' near Begreda, Bii-Khem

мужчина держит коня за поводья. В правой руке у него нож в ножнах, на вид дорогой, со вставками и, предположительно, таакиы xaвbl 'кисет'. Второй стоит справа, за всадником. В левой руке держит кусок ткани (кадак?). Оба мужчины одеты в традиционную одежду тувинцев из более простой на вид ткани. На голове широкая шапка калбак бөрт. Как его описывает Р. Б. Ховалыг, это капорообразный головной убор, скроенный из двух одинаковых половин ткани, войлока или овчины, мехом внутрь, с наушниками, которые завязывались на затылке, и назатыльником, прикрывавшим шею; один из древних головных уборов, который известен со скифского времени [Ховалыг 2018: 91].

Все трое обуты в кадыг идик - кожаные сапоги с загнутым вверх носком. Снимок

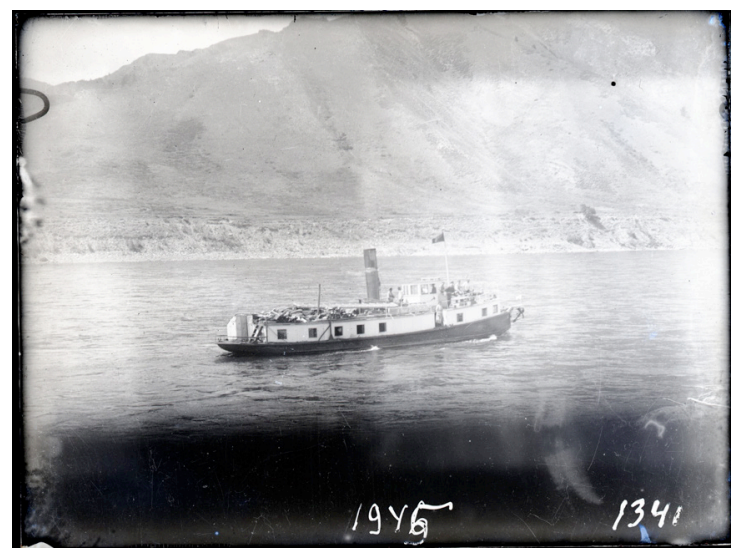

- видимо, репродукция, так как на пленке (целлулоид, фотопечать, 3,5x3,5 см). Датирован 1915 г., хотя экспедиция состоялась в 1913 г. Такую путаницу в датах у В. П. Ермолаева можно объяснить давностью лет. Или, возможно, была сделана опечатка при составлении коллекционной описи.

О буддийском ламе с негатива «Лама лекарь. 1916 г.» (КП 11286/98, стекло, фотоэмульсия, фотопечать, $12,8 \times 9,8$ см) в своем третьем рассказе «Ламы, судьи и купцы» из цикла «Давно это было», В. П. Ермолаев пишет: «Когда я фотографировал Кара-Хуртэна, он очень охотно позировал: уселся в позе Будды, скрестив ноги, над головой поднял какие-то иконки на манер староверских складней. Так я его и запечатлел» [Ермолаев 1967: 139]. 


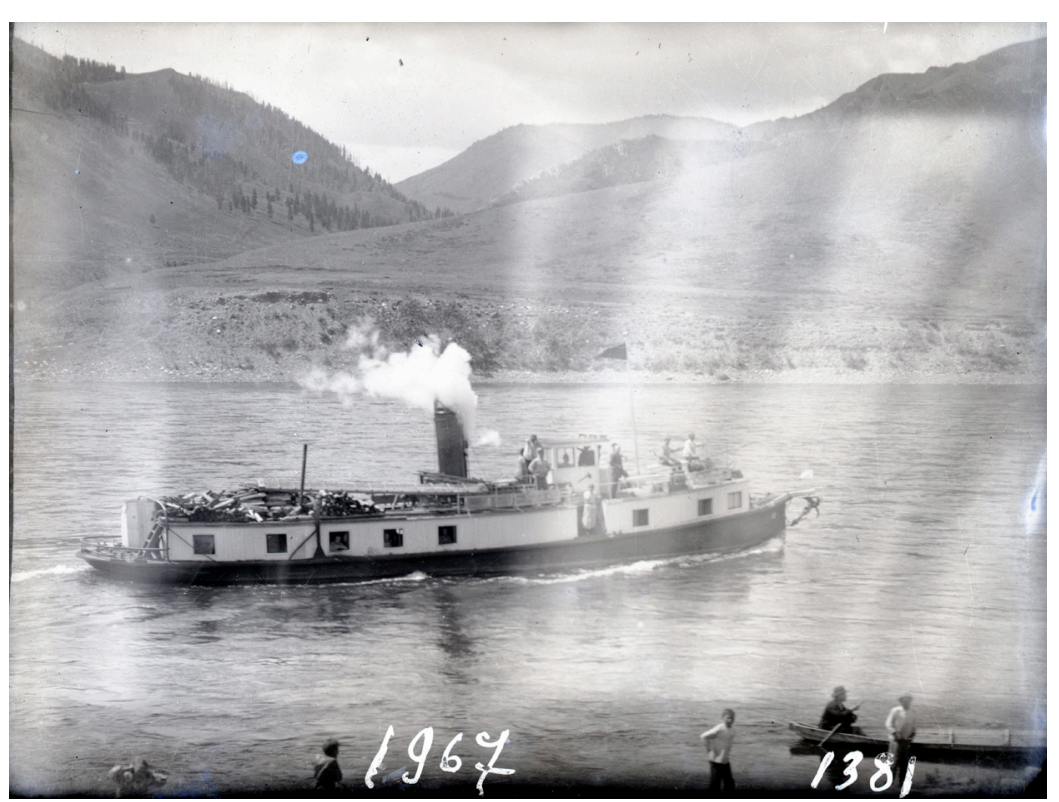

Фото 6.

Пароход «Минусенок» плывет к Хутинскому порогу на Пий-Хеме (КП 11286/1967)

[Photo 6. Steamer 'Minusenok' approaching the Khutinsky Rapids, Bii-Khem]

Действительно, на снимке изображен буддийский лама (учитель, проповедник), сидящий, скрестив ноги. В руках, поднятых над головой, он держит три небольших изображения буддийских устрашающих божеств, в правой руке дополнительно четки. Головной убор ламы трудно описать в виду того, что он закрыт изображениями божеств. Одет он в национальную одежду тон туникообразного покроя без воротника, опоясан матерчатым поясом, на котором висит плоский прямоугольный предмет, зауженный кверху. На ногах традиционные кадыг идик 'кожаные сапоги с загнутым вверх носком'. На правом колене, на ткани со специально пришитым ремешком для привязывания - барындак (буддийские книги обычно заворачиваются в прямоугольный или квадратный кусок ткани) лежит раскрытая буддийская книга судyp - возможно, молитвенник. Перед правым коленом на земле поставлена пиала. На шее у ламы металлические чехлы для хранения буддийских изображений. Несмотря на то, что Ермолаев в своем рассказе называет Кара-Хуртэна «старый пройдоха» [Ермолаев 1967: 138], на вид он мужчина средних лет со светлыми глазами. Под губами маленькая бородка. Волосы короткие с проседью. На заднем фоне часть юрты с открытой дверью. Далее узнаем, что сфотографировал он его в Шагонарской долине, на берегу реки Чааты в период перекочевок аратов на зимние стойбища, т. е. осенью 1916 года.
Еще один снимок «Первый пароход в Туве «Минусенок» на пути к Хутинскому порогу. 1925 г.» (КП 11286/3914, стекло, фотоэмульсия, фотопечать, 9,9х14,9 см) связан с рассказом В. П. Ермолаева «Енисей - великая река». «Маленький пароходик „Минусенок“ в 1924 году с помощью лебедок перебрался через большой порог, - писал он. - С помятыми боками и одной пробоиной пришел он в Кызыл. < ..> Ремонтной базы в Кызыле не было. Пришлось команде „Минусенка“ своими средствами залечивать раны. За зиму справились. Заделали пробоины, сменили несколько листов обшивки, исправили погнутый руль. Весной 1925 года пароход мог начать разведочные рейсы, а в середине лета была сделана попытка дойти до Хутинского порога» [Ермолаев 1969: 160].

На снимке запечатлен пароход - судно с паровым двигателем, приставшее к правому берегу реки. От судна на берег переброшен трап-лесенка, на котором стоит лысый мужчина в темных штанах и в более светлой, чем штаны, рубашке с длинными рукавами, подпоясанной широким кожаным ремнем. Мужчина держит руки в карманах штанов. Нос парохода (передняя по ходу часть судна) направлен вверх по течению реки. Мужчина в светлом плаще с капюшоном сидит на скамейке у левого борта, облокотившись о поручень. В углу капитанского мостика на передней палубе стоит женщина в рубашке с засученными рукавами и в юбке, она оперлась на правую руку и что-то держит в ней. 
С капитанского мостика выглядывает мужчина в шапке. У него борода по грудь и усы.

Вокруг трубы парохода на задней палубе уложены дрова в два ряда. Снизу расположены семь прямоугольных иллюминаторов парохода. Видно, что из одного иллюминатора выглядывает человек. На корме укреплена лодка. На правом берегу, сразу за пароходом возвышается гора с редкими деревьями в расщелинах и складках. На фоне горы заметен туман. Слева видны извилистые берега реки, поросшие деревьями и кустарниками. Владимир Петрович, описывая эту поездку, упоминал: «Пассажиров было немного - по одному представителю от Центросоюза, Госторга, местной кооперации и нас двоих от кружка урянховедения. Начальником этой импровизированной экспедиции был заведующий пароходством Верхнего Енисея Лукьянов. От Тувинценкоопа - Суховский, от Госторга - Cеребренников. Основная цель: разведка русла реки до порога, а если будет возможность, то и за порогом, на предмет использования водного пути для переброски грузов в Тоджинский район» [Ермолаев 1969: 160]. Также В. П. Ермолаев упоминает лоцмана Полежаева, повариху Аксюшу и капитана, фамилия которого ему не запомнилась.

Два негатива без датировки «Пароход „Минусинск“, недалеко от Бегреды, ПийХем» (КП 11286/1945, стекло, фотоэмульсия, фотопечать, 8,9х11,8) и «Пароход „Минусенок“ плывет к Хутинскому порогу на Пий-Хеме» (КП 11286/1967, стекло, фотоэмульсия, фотопечать, 8,8x11,9) можно датировать этим же 1925 г., так как на снимках, при сравнении с датированным снимком, запечатлен тот же пароход с правого борта.

\section{Источники}

НМ РТ - Национальный музей Республики Тыва.

Sources

National Museum of the Republic of Tuva.

\section{Литература}

Айыжы, Мандан-Хорлу, Монгуш 2019 - Aйblжы Е. В., Мандан-Хорлу М. М., Монгуш А. Ч. Коллекция В. П. Ермолаева как этнографический источник изучения материальной и духовной культуры тувинского этноса. Oriental Studies. 2019. № 4. C. 669-681. DOI: 10.22162/2619-0990-2019-44-4-669-681.
Надо сказать, что В. П. Ермолаев большинство своих рассказов написал в 1960-е годы на основе своих фотографий, вспоминая события, связанные с ними. Это рассказы «По следам старых фотографий» [Ермолаев 1964а], «Старые фотографии рассказывают» [Ермолаев 1964б] и другие [Ермолаев 2012].

Таким образом, В. П. Ермолаев многие свои рассказы связал со своими снимками, поэтому атрибуция его фотографий и негативов в тесной увязке с его публицистикой может быть продолжена.

\section{Заключение}

Таким образом, можно сделать вывод, что коллекция В. П. Ермолаева до сегодняшнего дня представляет интерес и ценность ввиду того, что у ученых имеются разные взгляды и суждения на отдельные периоды истории Тувы. Кроме того, в некоторых не вошедших в коллекцию альбомах имеются личные комментарии самого В. П. Ермолаева, что, несомненно, является важным историческим источником. Коллекция В. П. Ермолаева - это не только негативы, но и альбомы с фотографиями, которые нужно детально изучить. Существует острая необходимость их атрибуции, описания и создания справочного материала. Актуально и создание каталогов на эти музейные предметы для большей доступности той редкой и уникальной информации, содержащейся в них, для посетителей, ученых, краеведов, этнографов и т. д. Большая часть негативов не имеет научных паспортов, на сегодня научную обработку прошло всего лишь 144 негатива в целом из 4000.

Баташев, Мартынович 2007 - Баташев M. C., Мартынович Н. В. История формирования коллекции стеклянных негативов по этнографии коренных народов Средней Сибири Красноярского краевого краеведческого музея // Енисейская провинция. Вып. 3. Красноярск: Краснояр. гос. пед.ун-т им. В. П. Астафьева, 2007. С. 95-103.

Ермолаев 1967 - Ермолаев В. П. Давно это было // Улуг-Хем: альманах. 1967. № 9. С. $130-153$.

Ермолаев 1969 - Ермолаев В. П. Енисей - великая река: очерк // Улуг-Хем: альманах. 1969. № 10. С. 160-164. 
Ермолаев 1964a - Ермолаев В. П. По следам старых фотографий // Тувинская правда. 1964. 18 марта. С. 4.

Ермолаев 19646 - Ермолаев В. П. Старые фотографии рассказывают // Тувинская правда. 1964. 25 марта. С. 4.

Ермолаев 2012 - Владимир Петрович Ермолаeв - - очевидец великих перемен: избранные работы / Нац. музей им. Алдан-Маадыр Респ. Тыва; сост.: А. О. Дыртык-оол, У. Б. Нурзат. Кызыл: Аныяк, 2012. 196 с.

Монгуш 2013 - Монгуш О. О. Фотографии В. П. Ермолаева как исторический источник. // Первые республиканские Ермолаевские краеведческие чтения, посвященные 120 -летию со дня рождения первого директора Национального музея Республики Тыва Владимира Петровича Ермолаева (г. Кызыл, 9-10 октября 2012 г.). Сб. мат-лов / сост. У. Б. Нурзат / Национальный музей имени Алдан-Маадыр Республики Тыва. Кызыл: Аныяк, 2013. С. 41-44.

Ооржак 2009 - Ооржак A. М. Фотоматериалы об участии Тувы в Великой Отечественной войне 1941-1945 гг. в фондах Национального музея Республики Тыва // Наследие народов Центральной Азии и сопредельных территорий: изучение, сохранение и использование. Мат-лы Междунар. науч.-практ. конф. (г. Кызыл, 9-10 сентября 2009 г.). В 2-Х ч. Ч. II. На рус., англ и тув. яз. / сост. У. Б. Нурзат. Кызыл: Аныяк, 2009. С. 159 161.

Фотография 1992 - Фотография. Энциклопедический справочник / П. И. Бояров и др. Минск: Беларуская энциклапедыя имени Петруся Бровки, 1992. 402 с.

Ховалыг 2018 - Ховальг Р. Б. Тувинская традиционная одежда. Тыва үндезин хеп. Новосибирск: Наука, 2018. 335 с.

Черно-белая Тува 2011 - Черно-белая Тува: незаконченная история...= Black and white Tuva: Unfinished story...: Фотоальбом / авт.сост. С. Шойгу, дизайн и произв.: А. Агафонов [и др.]. М.: МобилАрт, 2011. 239 с.: ил.

\section{References}

[Photography: an Encyclopedic Directory]. P. I. Boyarov et al. (comps.). Minsk: P. Brovka Belarusian Encyclopedia, 1992. 402 p. (In Russ.)
[The Black and White Tuva: an Unfinished Story...]. A photo album. S. Shoygu (comp.). Moscow: MobilArt, 2011. 239 p. (In Russ.)

[Vladimir P. Yermolaev: He Who Witnessed the Great Changes. Selected Works]. Aldan-Maadyr National Museum of the Republic of Tuva. A. O Dyrtyk-ool, U. B. Nurzat (comps.). Kyzyl: Anyyak, 2012. 196 p. (In Russ.)

Ayizhy E. V., Mandan-Khorlu M. M, Mongush A. Ch. V. P. Yermolaev's collection as an ethnographic source for studies of Tuvan material and spiritual culture. Oriental Studies. 2019. No. 4. Pp. 669-681. (In Russ.) DOI: 10.22162/26190990-2019-44-4-669-681.

Batashev M. S., Martynovich N. V. The collection of glass negatives dealing with ethnography of mid-Siberia's native populations contained in Krasnoyarsk Local History Museum: a history of formation. Yeniseyskaya provintsiya. Is. 3. Krasnoyarsk: Astafiev Krasnoyarsk State Pedag. Univ., 2007. Pp. 95-103. (In Russ.)

Khovalyg R. B. [Tuvan Traditional Costume]. Novosibirsk: Nauka, 2018. 335 p. (In Russ. and Tuv.)

Mongush O. O. V. P. Yermolaev's photographs as a historical source. In: [First Republican Yermolaev Local History Readings Celebrating the $120^{\text {th }}$ Anniversary of V. P. Yermolaev's Birth]. Coll. papers. (Kyzyl; October 9-10, 2012). U. B. Nurzat (comp.). Aldan Maadyr National Museum of the Republic of Tuva. Kyzyl: Anyyak, 2013. Pp. 41-44. (In Russ.)

Oorzhak A. M. Photo materials about Tuva's participation in the Great Patriotic War of 19411945: collections of the National Museum of the Republic of Tuva. In: [The Heritage of Central Asian and Neighboring Peoples: Investigation, Preservation and Use]. Conf. proc. (Kyzyl; September 9-10, 2009). In 2 parts. Part II. U. B. Nurzat (comp.). Kyzyl: Anyyak, 2009. Pp. 159-161. (In Russ., Eng. and Tuv.)

Yermolaev V. P 'Stories told by old photographs'. Tuvinskaya Pravda. 1964, March 25. (In Russ.) Yermolaev V. P. 'Following old photographs'. Tuvinskaya Pravda. 1964, March 18. (In Russ.) Yermolaev V. P. 'That was long ago'. Ulug-Khem: almanac. 1967. No. 9. Pp. 130-153. (In Russ.)

Yermolaev V. P. 'The Yenisey is a great river'. UlugKhem: almanac. 1969. No. 10. Pp. 160-164. (In Russ.) 